\author{
KAROL KICZKA \\ ORCID: 0000-0002-3056-024X \\ Uniwersytet Wrocławski \\ Instytut Nauk Administracyjnych \\ Zakład Publicznego Prawa Gospodarczego
}

\title{
Z ZAGADNIEŃ SĄDOWEJ OCHRONY PRZEDSIĘBIORCÓW W SPOŁECZNEJ GOSPODARCE RYNKOWEJ
}

\begin{abstract}
Abstrakt: Konstytucyjnie określona społeczna gospodarka rynkowa zakłada aktywną rolę władzy publicznej w domenie gospodarowania. Regulacje prawne winny sprzyjać urzeczywistnianiu wolności działalności gospodarczej oraz realizacji ważnego interesu publicznego. Na gruncie obrotu gospodarczego nieuniknione są jednak spory pomiędzy przedsiębiorcami a organami administracji gospodarczej. Spory te powinny rozstrzygać właściwe krajowe, unijne i międzynarodowe sądy. Przywołane w opracowaniu orzeczenia potwierdzają, że sądy administracyjne w Polsce chronią wolność działalności gospodarczej i własność przedsiębiorców.
\end{abstract}

Słowa kluczowe: przedsiębiorca, społeczna gospodarka rynkowa, ochrona prawna

\section{WPROWADZENIE}

W społecznej gospodarce rynkowej sytuacja prawna przedsiębiorców i pozycja organów reprezentujących władzę publiczną jest kształtowana prawem. Organy władzy publicznej działają na podstawie i w granicach prawa. Konstytucja jest najwyższym prawem Rzeczypospolitej Polskiej (dalej: RP), której przepisy stosuje się bezpośrednio, chyba że Konstytucja stanowi inaczej. RP przestrzega wiążącego ją prawa międzynarodowego. Społeczna gospodarka rynkowa oparta na wolności działalności gospodarczej, własności prywatnej oraz solidarności, dialogu i współpracy partnerów społecznych stanowi podstawę ustroju gospodarczego RP. Rzeczpospolita Polska chroni własność i prawo dziedziczenia. Ograniczenie wolności działalności gospodarczej jest dopuszczalne tylko w drodze ustawy i tylko ze względu na ważny interes publiczny. Każdy ma prawo do sprawiedliwego i jawnego rozpatrzenia sprawy bez nieuzasadnionej zwłoki przez właściwy, niezależny, bezstronny i niezawisły sąd. Każdemu zasadniczo zapewnia się wolność 
wyboru i wykonywania zawodu oraz wyboru miejsca pracy. Każda ze stron ma prawo do zaskarżenia orzeczeń i decyzji wydanych w pierwszej instancji ${ }^{1}$.

Normy Konstytucji, w tym zwłaszcza przywołane wyżej, mają istotne znaczenie dla ochrony przedsiębiorców w społecznej gospodarce rynkowej. Konstytucja jest zatem — jak stwierdza Tadeusz Bigo — założeniem i podstawą całego porządku prawnego i wszelkiej działalności państwowej. Ten charakter przypisujemy zaś konstytucji jako całości, nie wyłączając ogólnych postanowień rozdziału I (tak zwanego dekalogu). Przepisy dekalogu są bowiem czymś więcej niż teoretycznym wykładem ideologii. Jeśli niektóre z nich nie mają sprecyzowanej formy nakazów prawniczych, to zawierają w każdym razie wypowiedź oceny i wskazanie ogólne. Są normami interpretacyjnymi — jak zaznaczał dalej Bigo — które nie tylko z powodzeniem spełnią rolę dyrektyw dla ustawodawcy, ale - jak to wykazała judykatura sądowa w okresie konstytucji marcowej - mogą często znaleźć bezpośrednie zastosowanie przy rozstrzyganiu konkretnych wypadków² ${ }^{2}$.

Celem opracowania jest analiza określonych aspektów sądowoadministracyjnej ochrony przedsiębiorców w społecznej gospodarce rynkowej w świetle uwarunkowań prawnych i opinii naukowych. W rozważaniach wykorzystany zostanie również wybrany materiał z praktyki stanowienia i stosowania prawa. Tytułowa tematyka ma doniosłe znaczenie dla właściwego funkcjonowania podmiotów gospodarczych (przedsiębiorców) w społecznej gospodarce rynkowej, w tym zwłaszcza ochrony swoistej dla nich wolności (wolności działalności gospodarczej) oraz ich aktywów (zasobów majątkowych) składających się na przedsiębiorstwo ${ }^{3}$. Gwarantowana i realizowana za pośrednictwem porządku prawnego ochrona wspomnianej wolności i zasobów majątkowych (własności i praw majątkowych) jest zazwyczaj czynnikiem uwzględnianym przy podejmowaniu mikro- i makrodecyzji biznesowych.

\section{PAŃSTWO A GOSPODARKA}

Cezary Kosikowski trafnie stwierdza, że „nocne stróżowanie” państwa w gospodarce należy już do przeszłości. Dzisiaj dba się o sprawną gospodarkę i finanse publiczne, ponieważ służą one osiąganiu celów społecznych o charakterze cywi-

1 Artykuł 20 Konstytucji Rzeczypospolitej Polskiej z dnia 2 kwietnia 1997 roku (Dz.U. 78, poz. 483, sprost. Dz.U. z 2001 r. Nr 28, poz. 319; Dz.U. z 2006 r. Nr 200, poz. 1471) (dalej: Konstytucja RP). Zob. A. Sajo, R. Uitz, The Constitution of Freedom. An Introduction to Legal Constitutionalism, Oxford 2017, s. 12.

2 T. Bigo, Wytyczne dla prawa administracyjnego w Konstytucji Polskiej r. 1935, Warszawa 1936, s. 3. Por. J. Boć, Konstytucja a prawo administracyjne, „Ruch Prawniczy, Ekonomiczny i Socjologiczny" 2011, z. 2, s. 70; B. Limperg, Zaufanie i rzady prawa, [w:] Przyszłość Europy opartej na rządach prawa. Studia i analizy Sąu Najwyższego. Materiały naukowe, t. 8, Warszawa 2019, s. 15-21.

3 Artykuł 3 ust. 1 pkt 12 ustawy z dnia 29 września 2019 roku o rachunkowości (Dz.U. z 2019 r. poz. 351 z późn. zm.). 
lizacyjnym, wytyczonych w formie wzorców i standardów oraz prawa w ramach interwencjonizmu realizowanego w skali międzynarodowej i unijnej. Wynika to wyraźnie - jak akcentuje C. Kosikowski - z zadań i celów, jakie stawiają sobie organizacje międzynarodowe i Unia Europejska (dalej: UE), interweniując w funkcjonowanie współczesnych społeczeństw i państw ${ }^{4}$.

Analiza wartości i zasad wyrażanych w Konstytucji RP w odniesieniu do stosunków gospodarczych była niejednokrotnie przedmiotem wypowiedzi Trybunału Konstytucyjnego (dalej: TK $)^{5}$. Społeczna gospodarka rynkowa zakłada odpowiedzialność państwa za stan gospodarki. W świetle poglądów TK użycie w art. 20 Konstytucji kwantyfikatora „społeczny” w szczególności: a) wyklucza wprowadzenie ,czysto liberalnego pojmowania ustroju gospodarczego, które odrzucało jakąkolwiek ingerencję państwa w funkcjonowanie mechanizmów rynkowych i oparte było na maksymalizowaniu własnych korzyści przez pracodawcę"; b) upoważnia państwo do podejmowania „działań łagodzących społeczne skutki funkcjonowania praw rynku, ale jednocześnie dokonywanych z poszanowaniem tych praw"; c) upoważnia państwo do podejmowania działań ingerujących w mechanizm wolnorynkowy, o ile nie są one dokonywanie w formie bezpośrednio skutecznych władczych rozstrzygnięć kształtujących status rynkowy podmiotów prawa prywatnego; d) wymaga, aby „państwo i inne instytucje publiczne w stosunkach z podmiotami z sektora prywatnego (w stosunkach zewnętrznych z punktu widzenia instytucji publicznych) działały w formach i na zasadach rynkowych"6.

Obowiązujące obecnie Prawo przedsiębiorców ${ }^{7}$ zakłada odejście od zbyt drobiazgowego normowania wielu spraw na rzecz uregulowań o charakterze jedynie podstawowym i dostatecznie ogólnym. Pozwoli to dokładnie regulować poszczególne kwestie w ustawach odrębnych zgodnie ze specyfiką przedmiotowej materii lub dziedziny, przy jednoczesnym zachowaniu prymatu pp i jego organizatorskiej roli w odniesieniu do przepisów ustaw odrębnych adresowanych do uczestników życia gospodarczego ${ }^{8}$.

${ }^{4}$ C. Kosikowski, Wspótczesny interwencjonizm, Warszawa 2018, s. 19-20. Por. Konstytucja gospodarcza Unii Europejskiej. Aksjologia, red. A. Nowak-Far, Warszawa 2010.

5 C. Banasiński, Prawo administracyjne gospodarcze, [w:] Prawo gospodarcze. Zagadnienia administracyjnoprawne, red. H. Gronkiewicz-Waltz, M. Wierzbowski, Warszawa 2017, s. 19-27.

${ }^{6}$ Wyrok TK z dnia 16 października 2014 roku, sygn. SK 20/12, Orzecznictwo Trybunału Konstytucyjnego, Zbiór Urzędowy 2014, nr 9, poz. 102. Por. Zasady ustroju społecznego i gospodarczego w procesie stosowania Konstytucji, red. C. Kosikowski, Warszawa 2005.

7 Ustawa z dnia 6 marca 2018 roku Prawo przedsiębiorców (Dz.U. z 2019 r. poz. 1292 z późn. zm.) (dalej: pp). Pp, jak wiadomo, zastąpiło uprzednio obowiązującą ustawę z dnia 2 lipca 2004 roku o swobodzie działalności gospodarczej (Dz.U. z 2016 r. poz. 1829 z późn. zm.).

${ }^{8}$ Uzasadnienie, druk nr 2055, rządowy projekt ustawy Przepisy wprowadzające ustawę Prawo przedsiębiorców oraz inne ustawy dotyczące działalności gospodarczej. Uprzednio projekt ustawy z dnia 26 stycznia 2018 roku Prawo przedsiębiorców. 
Znaczenie pp w naszym porządku prawnym uwypukla ulokowana w nim preambuła:

Kierując się konstytucyjną zasadą wolności działalności gospodarczej, a także innymi zasadami konstytucyjnymi mającymi znaczenie dla przedsiębiorców i wykonywanej przez nich działalności gospodarczej, w tym zasadami praworządności, pewności prawa, niedyskryminacji oraz zrównoważonego rozwoju, uznając, że ochrona i wspieranie wolności działalności gospodarczej przyczyniają się do rozwoju gospodarki oraz do wzrostu dobrobytu społecznego, dążąc do zagwarantowania praw przedsiębiorców oraz uwzględniając potrzebę zapewnienia ciągłego rozwoju działalności gospodarczej w warunkach wolnej konkurencji, uchwala się, co następuje.

Projekt pp przygotowała Rada Ministrów jako jeden z centralnych elementów przebudowy i reformy prawno-instytucjonalnego otoczenia przedsiębiorców oraz wykonywanej przez nich działalności gospodarczej. Projekt ten stanowił realizację formułowanych w Planie na Rzecz Odpowiedzialnego Rozwoju oraz Strategii na Rzecz Odpowiedzialnego Rozwoju zapowiedzi uchwalenia nowego aktu normatywnego, który miał w sposób całościowy i spójny regulować ogólne zasady wykonywania działalności gospodarczej w Polsce i który — tworząc korzystne, przejrzyste i stabilne warunki do prowadzenia działalności gospodarczej oraz wzmacniając gwarancje wolności i praw przedsiębiorców — zmniejszy ryzyko biznesowe oraz zwiększy chęć przedsiębiorców do podejmowania i wykonywania działalności gospodarczej, w tym także ich chęć do ponoszenia ryzyka technologicznego związanego z realizacją innowacyjnych projektów9 9

Pp, w założeniu projektodawców, to akt prawny, który ma w sposób spójny, całościowy i konsekwentny uregulować w Polsce ogólne zasady oraz reguły podejmowania, wykonywania i zakończenia działalności gospodarczej. Zawiera jedynie takie regulacje, które są rzeczywiście niezbędne dla instytucjonalnego wzmocnienia gwarancji wolności działalności gospodarczej oraz które będą dawały przedsiębiorcom wiarygodną $i$ autorytatywną informację o ich rudymentarnych prawach i obowiązkach $w$ ich stosunkach $z$ organami władzy publicznej i innymi podmiotami prawa, w tym z innymi przedsiębiorcami oraz konsumentami ${ }^{10}$.

W zakresie celu odnoszącego się do wolności działalności gospodarczej pp zmierza do stworzenia bardziej efektywnych niż dotychczas legislacyjnych gwarancji i zabezpieczeń dla niezakłóconego korzystania przez przedsiębiorców z tej wymienionej wolności, uznanej przez Konstytucję RP za jeden z filarów społecznej gospodarki rynkowej, a jednocześnie za podstawę ustroju gospodarczego RP (art. 20 Konstytucji RP). Pp, podobnie jak Konstytucja RP, ani nie tworzy, ani też nie przyznaje przedsiębiorcom wolności działalności gospodarczej. Wolność ta jest bowiem niezbywalnym prawem człowieka (oraz prawem określonych jedno-

9 Uzasadnienie, druk nr 2051, rządowy projekt ustawy Prawo przedsiębiorców. Por. A. Szafrański, Konstytucyjna wolność gospodarcza na tle historii idei i gospodarki, Warszawa 2018.

10 A. Szafrański, op. cit. Por. W. Małecki, Policja gospodarcza w prawie gospodarczym: ujecie teoretyczne, Warszawa 2019, s. 1-73. 
stek organizacyjnych tworzonych przez człowieka), przysługującym mu z uwagi na jego przyrodzoną godność, co Konstytucja RP oraz ustawodawstwo potwierdzają. Konstytucja RP oraz ustawy zwykłe tworzą natomiast (i powinny tworzyć) niezbędne prawne gwarancje i zabezpieczenia wolności działalności gospodarczej, w tym w postaci konkretnych obowiązków władz publicznych oraz skorelowanych z nimi uprawnień przedsiębiorców ${ }^{11}$.

Nadmienić należy, iż na gruncie nauk prawnych od dawna aprobowany jest pogląd, że:

Wolność jednostek jest zasadniczo nieograniczona, a ingerencja państwa jest czymś wyjątkowym, kontrolowanym, przydzielonym. Obok norm, określających interwencję państwa, władzy publicznej, przymusu, wdarcia się w sferę jednostek — istnieje zatem ogólna negatywna norma, wykluczająca wszelką ingerencję władzy publicznej, nie przewidziana przez prawo ${ }^{12}$.

Projektodawca pp przekonuje, że zadeklarowana w Konstytucji RP wolność działalności gospodarczej nakłada na władze publiczne szereg określonych rodzajowo obowiązków, ukierunkowanych ogólnie na zapewnienie jednostkom możliwie szerokiego zakresu swobody w dziedzinie gospodarowania oraz na zagwarantowanie jednostkom możliwości rzeczywistego korzystania z tej swobody. Do obowiązków władz publicznych implikowanych konstytucyjną wolnością działalności gospodarczej należą w szczególności: 1) obowiązek powstrzymania się od nieproporcjonalnej ingerencji w wolność jednostek do wykonywania i do zaniechania wykonywania działalności gospodarczej; 2) obowiązek stworzenia jednostkom instytucjonalnych gwarancji dochodzenia ich praw i roszczeń na wypadek naruszenia przez państwo obowiązku powstrzymywania się od nieproporcjonalnej ingerencji; 3) obowiązek zabezpieczenia wolności gospodarczej jednostek przed bezprawną ingerencją innych jednostek, a więc w relacjach horyzontalnych pomiędzy jednostkami; 4) obowiązek dokonywania pozytywnych świadczeń dla beneficjentów wolności gospodarczej wspierających wykonywaną przez nich działalność gospodarczą. W tym kontekście pp ma na celu praktyczne zrealizowanie tych wymienionych wyżej konstytucyjnych obowiązków władz publicznych w dziedzinie działalności gospodarczej, tak aby w pełniejszy i bardziej efektywny sposób zapewnić jednostkom możliwie szeroką swobodę w podejmowaniu, wykonywaniu i zakończeniu działalności gospodarczej ${ }^{13}$.

11 A. Szafrański, op. cit. Zob. Konstytucja Rzeczypospolitej Polskiej w pierwszych dekadach XXI wieku wobec wyzwań politycznych, gospodarczych i społecznych, red. S. Biernat, Warszawa 2013.

12 S. Rosmarin, Prawo podatkowe a prawo prywatne w świetle wykładni prawa, Lwów 1939, s. $197-198$.

13 Uzasadnienie, druk nr 2051, rządowy projekt ustawy Prawo przedsiębiorców. 


\section{SĄDY ADMINISTRACYJNE W SYSTEMIE OCHRONY PRZEDSIĘBIORCÓW}

Badanie przestrzegania prawa przez przedsiębiorców jest realizowane głównie w ramach nadzoru prawnego wykonywanego w imieniu państwa zazwyczaj przez organy administracji publicznej (organy administracji gospodarczej) $)^{14}$. Powstające na kanwie powyższego nierzadko spory są rozpatrywane przez właściwe organy wymiaru sprawiedliwości. Stosownie do treści art. 175 ust. 1 Konstytucji RP wymiar sprawiedliwości w RP sprawują Sąd Najwyższy, sądy powszechne, sądy administracyjne oraz sądy wojskowe. Naczelny Sąd Administracyjny (dalej: NSA) oraz inne sądy administracyjne sprawują, w zakresie określonym w ustawie, kontrolę działalności administracji publicznej. Kontrola ta obejmuje również orzekanie o zgodności z ustawami uchwał organów samorządu terytorialnego i aktów normatywnych terenowych organów administracji rządowej ${ }^{15}$. Tym samym dla ochrony prawnej przedsiębiorców w społecznej gospodarce rynkowej ważną rolę odgrywa w szczególności sądowoadministracyjna kontrola władzy wykonawczej (administracji gospodarczej).

Jerzy Stefan Langrod w okresie kształtowania państwowości w II Rzeczypospolitej uwypuklał znaczenie sądownictwa administracyjnego ze względu na jego wręcz wyjątkową, choć nie zawsze docenianą, wagę dla ustroju ówczesnego i przyszłego państwa. Chodzi tu w jego opinii o kontrolę nad dziedziną życia publicznego (władzą wykonawczą), która wskutek tradycji państwa absolutnego, w wyniku nieodporności wobec wpływów politycznych i ogromu agend jej przekazanych, jest szczególnie podatna na krzewienie się najszerzej pojętego bezprawia. Bezprawie to szczególnie szkodzi rozumnie pojętym interesom zbiorowym i indywidualnym ${ }^{16}$. Główna różnica między administracją publiczną a sądownictwem - jak pisze Franciszek Longchamps na kartach monografii wyeliminowanej z oficjalnego obiegu naukowego przez komunistyczne władze polskiego państwa - leży w różnicy postawy urzędnika administracyjnego i sędziego: urzędnik służył monarsze, sędzia społeczeństwu; urzędnik państwu, sędzia prawu $^{17}$.

14 Por. Funkcje administracji gospodarczej, [w:] J. Grabowski et al., Publiczne prawo gospodarcze. System prawa administracyjnego, t. 8a, red. R. Hauser, Z. Niewiadomski, A. Wróbel, Warszawa 2018.

15 Zob. A. Wasilewski, Władza sądownicza w Konstytucji Rzeczypospolitej Polskiej, „Państwo i Prawo" 1998, nr 7, s. 3; A. Zieliński, Środki ochrony wolności i praw wedtug nowej Konstytucji, „Państwo i Prawo” 1997, nr 11-12, s. 19. Por. M. Gersdorf, Przedmowa, [w:] Przyszłość Europy opartej na rzadach prawa..., s. 5-9.

16 J.S. Langrod, Kontrola administracji. Studja, Warszawa 1929, s. 13. Zob. Fenomen prawa administracyjnego. Ksiega jubileuszowa profesora Jana Zimmermanna, red. W. Jakimowicz, M. Krawczyk, Warszawa 2019.

17 F. Longchamps, Założenia nauki administracji, Wrocław 1949, s. 196. Zob. Pismo Ministerstwa Szkół Wyższych i Nauki z dnia 26 stycznia 1951 roku, nr DN-55/pfu/50.r. POUFNE. 
Przegląd praktyki wskazuje, że unormowaniami konstytucyjnymi stosowanymi w orzecznictwie sądów administracyjnych są między innymi art. 20 i 22 Konstytucji. Tytułem przykładu NSA analizował zagadnienie konstytucyjności zakazu reklamy aptek (art. 94a Prawa farmaceutycznego) ${ }^{18}$. Odwołując się do orzecznictwa TK, NSA stwierdził, że zakaz ten ogranicza wolność działalności gospodarczej w dopuszczalnym przez Konstytucję zakresie i formie. W pojęciu ważnego interesu publicznego, o którym mowa w art. 22 Konstytucji, mieści się ochrona zdrowia ludzkiego. Ta zaś może doznać uszczerbku nie tylko wskutek braku dostatecznego dostępu do leków, ale również wtedy, kiedy dostęp do leków jest zbyt łatwy, prowadzący do ich nadużywania. Taki skutek może wywołać ponadto obecna i sugestywna reklama zarówno leków, jak i aptek, leki nie są bowiem zwykłym towarem rynkowym. Obrót lekami musi być reglamentowany przez państwo. Prowadzący taką działalność nie mogą się cieszyć pełną wolnością gospodarczą. Powinny funkcjonować mechanizmy, które pozwalają na zakup leków wtedy, kiedy są one rzeczywiście niezbędne, a nie gdy pojawia się taka pokusa wywołana reklamą ${ }^{19}$.

Z kolei w sprawach zobowiązań podatkowych sądy administracyjne bardzo często odwołują się do standardów konstytucyjnych wywodzonych przede wszystkim z art. 84 i 217 Konstytucji, a także do dorobku orzeczniczego TK. NSA uwypukla, że dokonując interpretacji przepisów prawa podatkowego, należy dać prymat wykładni językowej, która powinna być uzupełniona o reguły wykładni systemowej i funkcjonalnej. Podkreślić należy przede wszystkim konieczność uwzględniania w procesie wykładni językowej nakazu dokonywania jej w zgodzie z hierarchicznie wyższymi normami systemu prawa. Konieczne jest zatem oparcie się także na regułach wykładni systemowej, zakładającej zgodność ustaw podatkowych z Konstytucją. $\mathrm{Z}$ kolei reguły wykładni celowościowej powinny być stosowane $\mathrm{w}$ ścisłym związku z wykładnią językową i systemową, gdyż nie mogą one samodzielnie prowadzić do rozszerzenia obowiązku podatkowego. Interpretacja in dubio pro fisco byłaby bowiem naruszeniem wartości i zasad konstytucyjnych ${ }^{20}$.

Jak wynika z analizy bieżącego orzecznictwa, kluczowe znaczenie dla ochrony przedsiębiorców mają równocześnie regulacje krajowe, unijne i prawnomiędzynarodowe. W myśl zwłaszcza art. 45 ust. 1 Konstytucji RP — jak podkreśla Wojewódzki Sąd Administracyjny we Wrocławiu ${ }^{21}$ — każdy ma prawo do sprawiedli-

18 Ustawa z dnia 6 września 2001 roku Prawo farmaceutyczne (Dz.U. z 2019 r. poz. 499 z późn. zm).

19 Informacja o działalności sądów administracyjnych w 2016 roku, Warszawa 2017, s. 279.

20 Informacja o działalności sądów administracyjnych w 2014 roku, Warszawa 2015, s. $307-$ 308.

21 Wyrok WSA we Wrocławiu z dnia 22 lipca 2019 roku, sygn. akt I SA/Wr 365/19 (orzeczenie nieprawomocne) CBOSA (dalej: WSA Wrocław). Por. L. Kieres, Niezawisty, bezstronny i niezależny sąd z perspektywy publicznego prawa gospodarczego, „Przegląd Prawa i Administracji” 103, 2015, s. 133-145. 
wego i jawnego rozpatrzenia sprawy bez nieuzasadnionej zwłoki przez właściwy, niezależny, bezstronny i niezawisły sąd (prawo do sądu). Funkcją sądów jest wymierzanie sprawiedliwości. „Prawo do sądu”, jako jedno z konstytucyjnych praw (i to praw „osobistych”), oznacza możliwość zwrócenia się w każdej sytuacji (sprawie) do sądu z żądaniem określenia (ustalenia) statusu prawnego jednostki. Odwołując się do wypowiedzi TK, WSA Wrocław akcentuje, że na treść prawa do sądu składają się: 1) prawo dostępu do sądu, to jest prawo uruchomienia procedury przed sądem - organem o określonej charakterystyce (niezależnym, bezstronnym i niezawisłym); 2) prawo do odpowiedniego ukształtowania procedury sądowej, zgodnie z wymogami sprawiedliwości i jawności; 3) prawo do wyroku sądowego, to jest prawo do uzyskania wiążącego rozstrzygnięcia danej sprawy przez sąd; 4) prawo do odpowiedniego ukształtowania ustroju i pozycji organów rozpoznających sprawy. Prawo jednostki do sądu jest realizowane przez całokształt zasad prowadzących do rzetelnego i merytorycznie prawidłowego rozpoznania sprawy w rozsądnym czasie. „Rozpatrywanie” oznacza wszechstronne zapoznanie się ze wszystkimi aspektami sprawy. Rozpatrzenie sprawiedliwe naturalnie koreluje z ogólną funkcją sądów, jaką jest wymierzanie sprawiedliwości. Oba te określenia wymagają, aby rozpatrując sprawy i ferując orzeczenia - przy działaniu na podstawie przepisów prawa, niezależnie i niezawiśle — sądy kierowały się w ich stosowaniu i interpretacji społecznym poczuciem sprawiedliwości, wszelako pamiętając również o wychowawczym aspekcie funkcji sądowniczej i nie kierując się mechanicznie opinią publiczną22.

WSA Wrocław podkreśla, że istotą sądowej kontroli administracji jest ochrona wolności i praw jednostki (podmiotów prawa) w stosunkach $\mathrm{z}$ administracją publiczną oraz budowanie i utrwalanie zasady państwa prawa i wyprowadzanych z niej standardów. Podstawową funkcją sądownictwa administracyjnego jest ochrona praw podmiotowych jednostki. Przyjęcie tej funkcji wypływa z założeń systemu weryfikacji administracji publicznej w państwie prawa, co ma związek z realizacją zasady praworządności. Z powyższego wynika, że sąd administracyjny jest obowiązany do stosowania tak zwanej prokonstytucyjnej wykładni prawa. Zgodnie z jej założeniami w przypadku, gdy określony przepis daje kilka możliwości interpretacji, należy przyjąć taki kierunek wykładni, który najpełniej odpowiada normom, zasadom i wartościom konstytucyjnym. Jest to obowiązek sądu wynikający z zasady nadrzędności Konstytucji. Wspomniana prokonstytucyjna interpretacja prawa jest jednym z rodzajów wykładni systemowej. Oznacza to, że błędne byłoby ograniczanie wykładni systemowej wyłącznie do ustawy, z której pochodzi interpretowany przepis, lub do innych ustaw regulujących daną dziedzinę prawa. Zawsze koniecznym elementem tego typu wykładni jest uwzględnienie regulacji konstytucyjnych. Ponadto, z uwagi na zasadę nadrzędności Konstytucji,

${ }^{22}$ L. Kieres, op. cit. Zob. Jednostka wobec władczej ingerencji organów administracji publicznej. Księga jubileuszowa dedykowana Profesor Barbarze Adamiak, red. J. Korczak, K. Sobieralski, Wrocław 2019. 
wykładnia prokonstytucyjna powinna mieć pierwszeństwo przed wykładnią funkcjonalną i celowościową, jak również wykładnią systemową wewnętrzną ${ }^{23}$.

Nie można zapominać, jak akcentuje WSA Wrocław, że w sprawach mających walor unijny sąd administracyjny jest sądem unijnym. Organy podatkowe (organy administracji publicznej) nie są również zwolnione z obowiązku dokonywania wykładni zgodnej z prawem unijnym, które stanowi element polskiego porządku prawnego (art. 87 ust. 1, art. 91 ust. 1 i 3 Konstytucji RP). W myśl orzecznictwa TSUE sądy krajowe są zobowiązane interpretować, w miarę możliwości, prawo krajowe w sposób zgodny z prawem UE. Taka wykładnia zgodna może być, co do zasady, powoływana wobec podatnika przez właściwy krajowy organ podatkowy. Do sądów krajowych i TSUE należy zapewnienie pełnego stosowania prawa Unii we wszystkich państwach członkowskich, jak również ochrony sądowej praw, jakie podmioty prawa wywodzą z prawa UE. Ponadto szeroki zakres zastosowania Karty Praw Podstawowych Unii Europejskiej (dalej: KPP/Karta) powoduje, że sądy administracyjne uzyskują rolę unijnych sądów konstytucyjnych badających nie tylko zgodność prawa krajowego z prawem unijnym, lecz także zgodność prawa krajowego z prawami podstawowymi uznanymi w systemie $\mathrm{UE}^{24}$.

Powyższe oznacza, że sędzia administracyjny zobowiązany jest interpretować prawo i kontrolować działania administracji publicznej w zgodzie z prawami podstawowymi. Dotyczy to także praw proceduralnych, ponieważ to dzięki nim jednostka egzekwuje swój godnościowy status. Kluczowym prawem jest, wynikające $\mathrm{z}$ art. $47 \mathrm{KPP}$, prawo do skutecznego środka prawnego i dostępu do bezstronnego sądu. W myśl wyżej wymienionego przepisu każdy, kogo prawa i wolności zagwarantowane przez prawo UE zostały naruszone, ma prawo do skutecznego środka prawnego przed sądem, zgodnie $\mathrm{z}$ warunkami przewidzianymi w niniejszym artykule. Każdy ma prawo do sprawiedliwego i jawnego rozpatrzenia jego sprawy w rozsądnym terminie przez niezawisły i bezstronny sąd ustanowiony uprzednio na mocy ustawy (zdanie drugie i trzecie przepisu). Po wejściu w życie traktatu z Lizbony (z dniem 2 grudnia 2009 roku, Dz.U. z 2009 r. Nr 203, poz. 1569) skuteczność ochrony sądowej uzyskała podwójną postać: skuteczność jako jeden $\mathrm{z}$ dwóch wymogów w zakresie autonomii proceduralnej państw członkowskich oraz skuteczność związana z prawem podstawowym do skutecznego środka prawnego przed sądem zgodnie $\mathrm{z}$ art. $47 \mathrm{KPP}^{25}$.

Jak zauważył przywoływany w przedstawianym orzeczeniu Rzecznik Generalny Michał Bobek w swojej opinii z dnia 10 kwietnia 2018 roku do sprawy C-89/17, EU:C:2018:225, pkt 101 n., na podstawie orzecznictwa TSUE można dojść do wniosku, że art. 47 KPP wyznacza aktualnie wyższy standard niż zasada skuteczności. W kontekście zasady skuteczności jako ograniczenia autonomii

\footnotetext{
23 L. Kieres, op. cit.

24 Ibidem.

25 Ibidem.
} 
proceduralnej państw członkowskich TSUE orzekł, że nie jest konieczne, by we wszystkich okolicznościach sądy mogły zastąpić decyzję własnym rozstrzygnięciem co do istoty sprawy i okoliczności faktycznych. Orzecznictwo TSUE pokazuje także, że kontrola sądowa, która jest ograniczona w odniesieniu do oceny określonych kwestii faktycznych, nie zawsze powoduje, iż wykonywanie praw wynikających z porządku prawnego UE staje się praktycznie niemożliwe lub nadmiernie utrudnione. Istotne jest to, że krajowa procedura kontroli sądowej umożliwia sądowi krajowemu rozpatrującemu skargę — w ramach kontroli jej zgodności z prawem - stosowanie odpowiednich zasad i norm prawa UE. Zakres i natężenie kontroli sądowej wymagane przez zasadę skuteczności zależą od treści i charakteru właściwych zasad i przepisów prawa UE implementowanych w zaskarżonej decyzji krajowej. Obowiązek przeprowadzenia bardziej kompleksowej kontroli, uwzględniającej ocenę faktów i merytorycznej trafności decyzji, zyskuje na znaczeniu w świetle wymagań art. 47 KPP wtedy, gdy takie badanie jest istotne, biorąc pod uwagę okoliczności konkretnej sprawy ${ }^{26}$.

Natomiast jeżeli chodzi o prawo dostępu do sądu, co podkreśla WSA Wrocław, TSUE orzekł, że aby sąd mógł zgodnie z art. 47 KPP podjąć decyzję w sprawie sporu dotyczącego praw i obowiązków wynikających z prawa UE, musi być uprawniony do zbadania wszystkich kwestii prawnych i faktycznych istotnych dla rozstrzyganego przez niego sporu. Przestrzeganie prawa do skutecznej ochrony sądowej musi zatem zostać zbadane w odniesieniu do specyficznego kontekstu i istotnych okoliczności danej sprawy, w szczególności charakteru rozpatrywanego aktu, okoliczności jego przyjęcia oraz przepisów prawa regulującego daną dziedzinę. W związku z tym, biorąc pod uwagę szczególne przepisy prawa UE i specyficzną naturę przedmiotowych praw i interesów, TSUE nalegał na potrzebę dogłębnej kontroli decyzji w odniesieniu zarówno do okoliczności faktycznych, jak i prawa, w szczególności wtedy, gdy rozpatrywany instrument obejmował już określone zharmonizowane standardy proceduralne ${ }^{27}$.

Ponadto przytaczane orzeczenie akcentuje, że w myśl art. 52 ust. $3 \mathrm{KPP}$ w zakresie, w jakim Karta zawiera prawa, które odpowiadają prawom zagwarantowanym w Konwencji o ochronie praw człowieka i podstawowych wolności (dalej: Konwencja ${ }^{28}$, ich znaczenie i zakres są takie same, jak prawa przyznane przez tę Konwencję. Powyższe nie stanowi przeszkody, aby prawo UE przyznawało szerszą ochronę. Stąd też naturalnym jest, aby po dalszą, ogólną inspirację sięgnąć do orzecznictwa Europejskiego Trybunału Praw Człowieka (dalej: ETPCz) dotyczącego wykładni art. 6 Konwencji. Na gruncie art. 6 ust. 1 Konwencji jedynie instytucja mająca pełną jurysdykcję zasługuje na miano „sądu”. Artykuł 6 ust. 1 Konwencji nakłada na sądy wymóg dokonania skutecznej sądowej oceny sprawy.

26 Ibidem.

27 Ibidem.

${ }^{28}$ Konwencja o ochronie praw człowieka i podstawowych wolności sporządzona w Rzymie 4 listopada 1950 roku (Dz.U. z 1993 r. Nr 61, poz. 284 z późn. zm.). 
Zasada, że sąd powinien sprawować pełną jurysdykcję, pociąga za sobą wymóg nierezygnowania przez sądy z żadnego elementu składowego ich funkcji orzekającej. Rozpatrujący sprawę „sąd” musi mieć jurysdykcję do zbadania wszystkich kwestii faktycznych i prawnych mających istotne znaczenie dla przedstawionego mu do rozstrzygnięcia sporu. ETPCz dostrzegał naruszenia art. 6 ust. 1 Konwencji wtedy, gdy kontrolujący sąd nie mógł orzec w przedmiocie głównego przedmiotu sporu lub gdy sądy krajowe uznawały się za związane uprzednimi ustaleniami organów administracyjnych, mającymi decydujące znaczenie dla rozpatrywanych przez te organy spraw, nie badając tych zagadnień w sposób niezależny ${ }^{29}$.

\section{WNIOSKI KOŃCOWE}

Przeprowadzone rozważania wskazują, że konstytucyjnie określona społeczna gospodarka rynkowa zakłada aktywną rolę władzy publicznej w domenie gospodarowania. Ustanawiane regulacje prawne winny sprzyjać urzeczywistnianiu wolności działalności gospodarczej oraz realizacji ważnego interesu publicznego. Ochrona i wspieranie przedmiotowej wolności przyczyniają się do rozwoju gospodarki oraz do wzrostu dobrobytu społecznego. Na gruncie obrotu gospodarczego nieuniknione są jednak spory pomiędzy przedsiębiorcami a organami administracji gospodarczej, które powinny rozstrzygać właściwe krajowe, unijne i międzynarodowe organy wymiaru sprawiedliwości. Jak trafnie pisze Marek Safjan: „Wadliwe prawo stało się nieomal elementem ornamentyki III Rzeczypospolitej, a prawne buble oraz legislacyjne potworki i potwory towarzyszą nam w każdej nieomal dziedzinie prawa" 30 . Sądy administracyjne w istotnym zakresie sprawują kontrolę działalności administracji publicznej w relacjach z podmiotami gospodarczymi na podstawie prawa krajowego, unijnego i międzynarodowego. Jak wykazują przywołane w opracowaniu judykaty, kontrola legalności organów administracji gospodarczej chroni wolność działalności gospodarczej i własność (zasoby majątkowe) przedsiębiorców. Zasada legalizmu od wieków jest postrzegana jako warunek dobrych rządów i pokoju społecznego. Państwo, wiążąc prawem swoich obywateli, musi tym prawem być związane i także mu podlegać. Już w I Rzeczypospolitej podkreślano, że to nie król, lecz prawo rządy sprawuje (Non rex sed lex regnat). Właściwie ukształtowany wymiar sprawiedliwości jest gwarancją pokojowych stosunków między obywatelami a państwem. Istotą funkcji państwa jest szczególna dbałość o legalizm, z którego wynika powinność sądów administracyjnych kontroli zgodności z prawem działań administracji publicznej31.

29 Ibidem.

30 M. Safjan, Odpowiedzialność odszkodowawcza z tytułu bezprawia normatywnego, „Ruch Prawniczy, Ekonomiczny i Socjologiczny" 2005, z. 1, s. 16.

31 Informacja o działalności sądów administracyjnych w 2017 roku, Warszawa 2018, s. 11. 


\title{
JUDICIAL PROTECTION OF ENTREPRENEURS IN THE SOCIAL MARKET ECONOMY. SOME PROBLEMS
}

\author{
Summary
}

The social market economy enshrined in the Constitution has envisaged an active role for administrative authorities in the field of the economy. Legal regulations in this field should promote both freedom of economic activity and implementation of important public interest. Nevertheless, conflicts in economic relations between entrepreneurs and authorities of economic administration are unavoidable. These conflicts should be settled by the competent domestic, European Union, and international courts. Relevant judgements discussed in this text confirm that administrative courts in Poland protect freedom of economic activity and property rights of entrepreneurs.

Keywords: entrepreneur, social market economy, legal protection

\section{BIBLIOGRAFIA}

Banasiński C., Prawo administracyjne gospodarcze, [w:] Prawo gospodarcze. Zagadnienia administracyjnoprawne, red. H. Gronkiewicz-Waltz, M. Wierzbowski, Warszawa 2017, s. 19-27.

Bigo T., Wytyczne dla prawa administracyjnego w Konstytucji Polskiej roku 1935, Warszawa 1936, s. 3.

Boć J., Konstytucja a prawo administracyjne, „Ruch Prawniczy, Ekonomiczny i Socjologiczny” 2011, z. 2, s. 70.

Fenomen prawa administracyjnego. Ksiega jubileuszowa profesora Jana Zimmermanna, red. W. Jakimowicz, M. Krawczyk, Warszawa 2019.

Gersdorf M., Przedmowa, [w:] Przyszłość Europy opartej na rzadach prawa. Studia i analizy Sądu Najwyższego. Materiały naukowe, t. 8, Warszawa 2019, s. 5-9.

Grabowski J. et al., Publiczne prawo gospodarcze. System prawa administracyjnego, t. 8a, red. R. Hauser, Z. Niewiadomski, A. Wróbel, Warszawa 2018.

Jednostka wobec władczej ingerencji organów administracji publicznej. Księga jubileuszowa dedykowana Profesor Barbarze Adamiak, red. J. Korczak, K. Sobieralski, Wrocław 2019.

Kieres L., Niezawisty, bezstronny i niezależny sąd z perspektywy publicznego prawa gospodarczego, „Przegląd Prawa i Administracji” 103, 2015, s. 133-145.

Konstytucja gospodarcza Unii Europejskiej. Aksjologia, red. A. Nowak-Far, Warszawa 2010.

Konstytucja Rzeczypospolitej Polskiej w pierwszych dekadach XXI wieku wobec wyzwań politycznych, gospodarczych i społecznych, red. S. Biernat, Warszawa 2013.

Kosikowski C., Wspótczesny interwencjonizm, Warszawa 2018, s. 19-20.

Langrod J.S., Kontrola administracji. Studja, Warszawa 1929, s. 13.

Limperg B., Zaufanie i rzady prawa, [w:] Przyszłość Europy opartej na rzadach prawa. Studia i analizy Sądu Najwyższego. Materiaty naukowe, t. 8, Warszawa 2019, s. 15-21.

Longchamps F., Założenia nauki administracji, Wrocław 1949, s. 196.

Małecki W., Policja gospodarcza w prawie gospodarczym: ujęcie teoretyczne, Warszawa 2019, s. $1-73$.

Rosmarin S., Prawo podatkowe a prawo prywatne w świetle wyktadni prawa, Lwów 1939, s. 197198.

Safjan M., Odpowiedzialność odszkodowawcza z tytułu bezprawia normatywnego, „Ruch Prawniczy, Ekonomiczny i Socjologiczny" 2005, z. 1, s. 16. 
Sajo A., Uitz R., The Constitution of Freedom. An Introduction to Legal Constitutionalism, Oxford 2017, s. 12.

Szafrański A., Konstytucyjna wolność gospodarcza na tle historii idei i gospodarki, Warszawa 2018.

Wasilewski A., Wtadza sądownicza w Konstytucji Rzeczypospolitej Polskiej, „Państwo i Prawo” 1998, nr 7, s. 3.

Zasady ustroju społecznego i gospodarczego w procesie stosowania Konstytucji, red. C. Kosikowski, Warszawa 2005.

Zieliński A., Środki ochrony wolności i praw wedtug nowej Konstytucji, „Państwo i Prawo” 1997, nr 11-12, s. 19. 